\title{
Changes in Beliefs Regarding Good Teachers and the Characteristics of Child Development of Primary Education Students
}

Helena Smrtnik Vitulič ${ }^{1}$ And Irena LesaR ${ }^{\star 2}$

$\propto$ In a longitudinal study, we determine the beliefs of primary education students regarding the factors of academic achievement, good teachers, and the developmental characteristics of children, and we present which experiences mostly shape these beliefs. The same group of students $(\mathrm{N}=59)$ completed the same questionnaire at the beginning of their first year and then at the end of their postgraduate studies. At both measurements, the students stated that the pupils themselves are the most responsible for their academic achievement (approximately 33\%). At the beginning of the study, the students mostly showed idealised beliefs regarding what makes a good teacher, such as he/she is self-controlled and calm in all situations; he/she likes all children equally, etc. At the end, the results showed a reshaping of most idealised beliefs about what makes good teachers towards more realistic ones. Regarding the developmental characteristics of children, at the beginning and at the end of their studies the students had similar beliefs that heredity and environment contribute to an individual's development. At the end of their studies, the students are significantly less convinced that experience from an early age decisively influences their further development, that there are no major differences in cognitive abilities of pupils of the same class, that a child who knows a lot of information is clever, and that school is not a place for the expression of emotions. According to the students, direct experiences in the classroom have the most significant influence on the beliefs among all the factors that we have examined in the study.

Keywords: beliefs, child development, good teacher, primary education, students

1 University of Ljubljana, Faculty of Education, Slovenia.

$2{ }^{\star}$ Corresponding Author. University of Ljubljana, Faculty of Education, Slovenia; irena.lesar@pef.uni-li.si. 


\section{Spremembe prepričanj študentov razrednega pouka o dobrem učitelju in značilnostih otrokovega razvoja}

Helena SMrtnik Vitulič in Irena Lesar

$\approx \mathrm{V}$ vzdolžni raziskavi ugotavljamo prepričanja študentov razrednega pouka o dejavnikih učnega (ne)uspeha, dobrem učitelju in o razvojnih značilnostih otrok ter predstavimo, katere izkušnje po samoporočanju študentov najbolj sooblikujejo ta prepričanja. Ista skupina študentov $(\mathrm{N}=59)$ je enak vprašalnik najprej izpolnila na začetku prvega letnika študija in nato ob koncu njihovega podiplomskega študija. Ob obeh merjenjih so študenti ocenili, da k učni (ne)uspešnosti učenca v največji meri prispeva učenec sam (približno v 33 \%), nato starši, učitelji in nazadnje vrstniki. Študentje so na začetku študija izražali predvsem idealizirane predstave o dobrem učitelju: da je miren in obvladan v vseh situacijah; da ima vse otroke enako rad; da zna motivirati vse otroke, tudi tiste, ki jih snov ne zanima; da zna naučiti vse učence, tudi tiste $\mathrm{z}$ nižjimi učnimi sposobnostmi. Ob koncu so rezultati pokazali na preoblikovanje večine predstav o dobrem učitelju v smeri bolj realističnih. Glede razvojnih značilnosti otrok pa so imeli študentje že na začetku študija bolj usklajena prepričanja $\mathrm{z}$ znanstvenimi spoznanji, saj so se le delno strinjali, da dednost določa posameznikov razvoj, da izkušnje iz zgodnjega otroštva odločujoče vplivajo na nadaljnji razvoj otroka, da ni bistvenih razlik v miselnih sposobnostih učencev istega razreda, da je otrok, ki pozna veliko informacij, pameten in da šola ni prostor za izražanje čustev. Stopnja strinjanja $\mathrm{z}$ večino trditev se je ob drugem merjenju pomembno znižala. Po mnenju študentov imajo neposredne izkušnje v razredu med vsemi dejavniki najpomembnejši vpliv na njihova prepričanja, ki smo jih preverjali v raziskavi.

Ključne besede: prepričanja, dober učitelj, razvoj otroka, študentje, osnovna šola 


\section{Introduction}

In the past ten years, researchers have been paying particular attention to the question of how to design a high-quality study process, which will enable the (future) teachers the acquisition of competencies to effectively stimulate development and pedagogical work in the classroom (Hermans, van Braak, \& Van Keer, 2008; Minor, Onwuegbuzie, Witcher, \& James, 2002). In this aspiration, it is of key importance to answer two basic questions: 1 ) What are the key qualities of a good teacher? and 2) How can we help students to become good teachers? (Korthagen, 2004).

While responding to a question about the key qualities of good teachers, we can rely on the theoretical pedagogical concepts (cultural pedagogy, reform pedagogy and socially-critical pedagogy) (Protner, 200o), which emphasise different opportunities of teacher influence on child development in educational practice - a deductive approach. We can also proceed from the empirical findings of quality pedagogical work of the teacher, which identify the characteristics of a 'good' teacher with different research methods - an inductive approach (e.g. Doolittle et al., 1993; Sanders, 2002). In this article, we will use the latter.

Regarding the beliefs about a good teacher and his/her work, we consider the individual's personal, subjective, implicit constructs or understanding and assumptions on the performance of the teaching profession, which are formed on the basis of experience and knowledge of a certain phenomenon (Herman et al., 2008; Valenčič Zuljan, 2012). Personal beliefs lead students to the fact that they filter which content and experiences during the study will be integrated into their knowledge and which will be rejected as unacceptable (Lofstrom \& Poom-Valickis, 2013; Pajares, 1992). Individuals form their beliefs about the teacher and the pupils on the basis of early experience, which they gained as pupils in the class. Previous experiences of students entering higher education can be even more crucial for the formation of beliefs, which they maintain in their work as teachers (Korthagen, 2004). One important factor for the creation of teachers' beliefs is the direct experience acquired by the student in contact with the pupils in the class, for example, practice during university education (Valenčič Zuljan, 2012). Despite beliefs being unlikely to change (Doolittle, Dodds, \& Placek, 1993), they can at least to some extent be changed by the deliberate and systematic construction of new meanings of individual experience or new skills acquired during the education for teachers (e.g. Korthagen, 2004). 


\section{Beliefs about the characteristics of a 'good teacher'}

The measurement of beliefs about the characteristics of a good teacher is complex, and it is largely based on the self-reporting of (future) teachers. In the research on beliefs about 'good teachers', qualitative-quantitative analyses are often combined (e.g. Minor et al., 2002). The most commonly used methods are questionnaires and interviews (e.g. Hermans et al., 2008; Minor et al., 2002), descriptors with the characteristics of teachers (e.g. Sanders, 2002), diary studies with personal descriptions of the teacher's performance (e.g. Doolittle et al., 1993) and metaphors (e.g. Löfström \& Poom-Valickis, 2013; Mishima, Horimoto, \& Mori, 2010; Thomas \& Beauchamp, 2011).

Although many of us have our own ideas about what makes something 'good', and how 'good' ranks on a scale of poor to excellent, we can accept the definition that 'good work is work that is excellent in quality, work that is ethical in terms of considering the impact of the work on others, and work that is engaging, or personally meaningful, for the individual worker' (Guidebook, 2010, p. 19). However, the fundamental concepts and organisational frameworks of the theory of the three 'E's of Good Work can be thought of, individually, in a number of ways; and that the ways in which the elements are integrated or, alternatively, dissociated from one another is far from self-evident (Gardner, 2010, p. 17).

Decades ago, Gordon (1983) queried over one thousand teachers and participants in his training on performance improvement, how to be a good teacher. Most of the teachers described a good teacher as entirely consistent, self-controlled and just, as a teacher who likes all children equally, without prejudice, he/she knows how to motivate all pupils, including those who are not interested in the subject, and if he/she works well, he/she has no disciplinary problems in the classroom, etc. Similar results about beliefs about good teachers were found in the study with 137 Slovenian primary school teachers (Šimonka \& Košir, 2014).

Minor and co-authors (2002) summarise the key findings of many studies and recommendations from relevant institutions in the field of teacher education (e.g. Cotton, 1995; Finn, 1993; Good/Brophy, 1994; National Board for Professional Teaching Standards [NBPTS], 1987; Redfield \& Rousseau, 1981; Rosenshine \& Stevens, 1986; Testing Service [ETS], 1997; Tobin, 1987; Wubbels, Larry, \& Brekelmans, 1997) about good teachers who are also called 'effective teachers.' ${ }^{3}$ Good teachers should be able to select and organise contents,

3 In some studies on beliefs, the researchers as a synonym of 'good teacher' also used the terms 'effective' or 'competent teacher' (Fajet, Bello Leftwich, Mesler \& Shaver, 2004). In this article we will use a uniform term 'good' teacher for the abovementioned terms. 
efficiently organise time, adapt teaching strategies to the needs of the learner, creatively encourage pupils, skilfully use questions, encourage critical and creative thinking, give relevant feedback, promote the learner's progress, fairly evaluate, reflect on their practice, and be ready to learn in their professional development.

In a study (Minor et al., 2002) in which 134 students from Georgia (USA) who were educated for the teaching profession were included, the participants wrote three to six descriptors, which they believed that every good teacher should have. The following most important characteristics of a good teacher which are classified within the individual descriptors, are the most frequently identified:

1. student-centred with descriptors 'love of a student', 'supportive', 'optimistic', 'kind', 'caring', and 'patient';

2. classroom and behaviour manager that include verbatim examples as 'authoritative', 'leadership skills', and 'alert';

3. competent instructor with descriptors 'reactivity', 'open to new teaching styles,' 'clarity and teaching subjects', and 'ability to spark child's interest';

4. ethical with descriptors 'fairness', 'honest', 'trustworthy', 'impartial', 'dependable', and 'reliable';

5. enthusiastic about teaching with examples 'of human subjects', 'passion for teaching,' 'eager to teach', and 'dedicated';

6. knowledge about subject descriptors include 'efficiently teach and know the material', and 'knowledge of subject'; and

7. professional with examples of 'disciplined', and 'good communicator'.

The results showed that the majority of students cited the following as the most important factors in teachers: he/she is student-centred (55\%), then the effective classroom and behaviour manager (34\%) and competent instructor (34\%), as well as ethical (30\%), enthusiastic about teaching (24\%), has knowledge about the subject (19\%), and he/she is professional (15\%).

\section{A more realistic conception of the characteristics of a 'good teacher' and the characteristics of pupils}

Given that the results of the aforementioned studies have shown that the teacher should have many attributes, we wonder which teachers are actually able to fully achieve them. Therefore, the previously described notions of a good teacher have been idealised and cannot be fully achieved (Gordon, 1983; Sutton, 2004). A teacher, who has idealised, overly high, and unrealistic expectations of 
himself/herself, will primarily blame himself/herself for the child's failure. This failure to meet the expectations will give rise to dissatisfaction, impatience, and fatigue (Bečaj, 1990; Šimonka \& Košir, 2014). Failing to achieve such ideals, the teacher will often experience a wide variety of adverse emotions such as anger, shame, sadness, etc., as confirmed by the interaction study of Slovenian teachers with pupils (Prosen, Smrtnik Vitulić, \& Poljšak, 2011).

It is interesting that many teachers have unrealistic notions in the field of their expression of bad feelings, namely, that a good teacher never loses control of their adverse feelings in front of the pupils in the class (Gordon, 1983; Hosotani \& Imai-Matsumura, 2011), which means that the intensive experience of adverse feelings that the teacher 'must not' show is particularly frustrating for them. In contrast, those teachers with the (false) belief that a good teacher always shows his/her emotions in front of pupils (e.g. Hosotani \& Imai-Matsumura, 2011), will mostly over-express their emotions or they will even pretend to have emotions that they do not (Prosen et al., 2011). In a survey of 109 Slovenian teachers, when observing their emotions in the classroom, anger was shown to be the most common emotion that was expressed by teachers mainly in response to discipline and the learning difficulties of pupils. Furthermore, the teacher's aim does not lie in the fact that all pupils in the class are happy all the time, but he can offer the conditions that allow the pupils to achieve their learning goals and develop themselves in a pleasant atmosphere (Šarić, 2015).

When we look for the key characteristics of a 'good teacher', we should proceed from the teacher's fundamental tasks of the profession, among which it is mainly to ensure the quality of educational work, which includes quality teaching and the creation of favourable conditions for the child's optimal development. 'Pupils should be given support in their struggle for independence and taking responsibility for their actions, and should be guided to the creation of an independent and responsible person who will be willing and able to use their knowledge to contribute to the development of the society as a whole' (Krek \& Metljak, 2011, p. 26).

The teacher is responsible for the quality of education and upbringing of pupils in the school context; therefore, it is a process that enables learning and promotes development. For the teachers to do their work well, it is essential that they have sufficient knowledge of the subject areas taught (an expert on the subject), to know the methods of teaching which facilitate the understanding of the learning content and stimulate the child's motivation to learn (an expert in teaching). It is also important that they promote the development of children in appropriate ways (an expert in how children are raised) (Thomas \& Beauchamp, 2011; Seung et al., 2011, in Lofstrom \& Poom-Valickis, 2013). 
When creating the right conditions for the development of pupil's learning and development capabilities, the teacher should be familiar with the basic development features, such as factors of personal development, individual (psychological) characteristics of children, capabilities that can be identified in children, etc. In the past twenty years, researchers (e.g. Howard-Jones, 2010; Plomin, 2004) have emphasised the importance of genetic and environmental factors for the development of most psychological characteristics of people. Psychological characteristics of individuals do not depend only on their innate characteristics, but they should be understood as a function operation of genes and the environment (e.g. Plomin, 2004). The so-called sensitive period exists in the time that is optimal for the development of some of the characteristics (e.g. for the development of attachment, learning speech, or a language), but this does not mean that later we cannot learn certain things or compensate (Bregant, 2012). For the teacher it is, therefore, necessary to identify a wide range of abilities of their pupils, bearing in mind that the development of them is strongly influenced by the milieu and that they can be very effectively promoted by the teacher. In a school context, the importance of the child's intelligence is most frequently highlighted and even if the concept of intelligence is a complex one and many different models of intelligence have been proposed, intelligence, in the broadest sense, may be defined as the ability to learn or understand things or to deal with new or difficult situations (Kail \& Cavanaugh, 2016).

For (future) teachers, in addition to the knowledge about the developmental characteristics of a child, understanding the factors that contribute significantly to pupils' academic achievement is also important. In previous studies, specific (psychological) characteristics of the pupil (personality traits, intellectual abilities, etc.), characteristics of the school/classroom/teachers (e.g. size of the school, school atmosphere, interaction between teachers and pupils, interactions among students, teaching methods), family characteristics (e.g. economic situation of the family, education of parents) and the characteristics of the peer group (peer group values) have proved to be very important (Puklek Levpušček \& Zupančič, 2009; Wang, Haertel, \& Walberg, 1993). It is difficult to precisely predict the effects of individual factors, since the effect of individual factors of academic achievement is not only a 'summation' in the sense that everyone 'adds' his contribution to academic achievement, but it is interactive (e.g. parental involvement in the school can be considered as an important factor of the academic achievement for low motivated pupils, but not for highly motivated) and/or indirect (e.g. teaching encourages the pupil's interest in the subject matter, so the teacher will contribute to his academic achievement through the pupil's motivation) (Puklek Levpušček \& Zupančič, 2009). 
It can be summarised that good teacher should be responsible for the quality of the process of education and for encouraging pupils' development in the school context. To accomplish this, it is necessary for a teacher to have sufficient knowledge of the subject, to know and use appropriate methods of teaching, and be familiar with the basic development features for promoting the development of children. In the present longitudinal study, we want to determine the beliefs of the primary education students on the factors of academic achievement, on a good teacher and developmental characteristics of children, and to explore which experiences primarily shape these beliefs.

\section{Research questions}

Four research questions concerning beliefs of the primary education students were addressed:

1. In what proportions different factors - in the opinions of students at the beginning and at the end of their studies - contribute to academic achievement of the pupil?

2. What are students' beliefs about good teachers at the beginning and at the end of their studies?

3. What are students' beliefs at the beginning and at the end of their study about the pupil's developmental characteristics?

4. Which are (un)important factors that shape students' beliefs at the beginning and at the end of their studies?

\section{Method}

In our longitudinal research, we used descriptive and non-experimental causal methods.

\section{Participants}

The study was based on an initial opportunity sample of 111 primary education students (95\% female) in the beginning of the first year of their study at the Faculty of Education in Ljubljana. The students were aged between 18.6 and 25.1 years $(\mathrm{M}=19.8$ years old, $\mathrm{SD}=0.7$ years $)$. Then, we looked for the same group of students four years later, when finalising their postgraduate studies for class teachers. Due to limited enrolment in postgraduate studies (81 of them were accepted) and the possibility that the Faculty of Education in Ljubljana also accepts students from other universities, we only had 70 students available (out 
of those who had participated in the first part of the study). Since 11 of them did not respond to a request to participate again, the sample was substantially smaller in the second part. The questionnaires were completed only by 59 female students from among those who had been included in the first part of the research.

\section{Instrument}

For the purpose of this study, which is based on relevant literature (e.g. Bečaj, 1990; Gordon, 1983; Hosotani \& Imai-Matsumura, 2011) and the education experiences of students of primary education at the Faculty, we developed a questionnaire with the aim of estimating the students' beliefs about good teachers and their knowledge regarding selected developmental characteristics of children.

The questionnaire included some basic demographic data (gender, identification number, year of study), then the question regarding the factors of academic achievement to which the participants added the percentage, followed by a description of five unrealistic (idealised) statements about a good teacher and five false statements about the (developmental) characteristics of children. For each of the following statements, the participants marked the degree of agreement on a five-point rating scale (1 - I disagree, 2 - I mostly disagree, 3 - I partly agree, partly not, 4 - I mostly agree, 5 - I totally agree). At the end, all the participants highlighted what they believed contributed most to forming beliefs included in the questionnaire (they could also select more answers).

\section{Procedure}

All the participants were fully informed about the purpose and methods of this study, and their participation was voluntary. First, data were collected at the beginning of the first year of their primary education studies, during the lectures. Four years later, during the second semester of their postgraduate studies, the students who had already taken part in the study, were again asked to participate. During their lectures, they completed the questionnaire which was the same as in the first year of their studies. In both instances, the completion of the inventory took about 15 minutes. All questionnaires were completely filled in and taken for further statistical analyses.

\section{Data analysis}

First, we wanted to confirm the assumption that for the participation in the second part of the study we did not include a specific group of students, but a group similar to that which did not take part in the second part of the study ( $47 \%$ dropout rate in the sample). The chi-squared tests for the determination 
of differences between the attributed share of factors and the non-parametric Mann-Whitney test for statements (due to the previously identified abnormalities in the distribution; the Shapiro-Wilk tests: all ps <.oo) showed that the two groups are similar.

Furthermore, we compared only the results obtained by those students $(\mathrm{N}=59)$ who participated in the first and second phases of the research. In their answers concerning the share of the four factors that contribute to a child's academic achievement, we calculated the average proportions of individual factors at both times of measurements. The difference in the percentage of shares between the two measurements was checked with the Wilcoxon signed-rank test. For each of the two items (the characteristics of a good teacher and the developmental characteristics of pupils), we calculated the average value of the results obtained for both measurements. Because of the already proven non-normality of the distribution, we then applied a set of non-parametric statistical procedures. With the Wilcoxon signed-rank test, we determined eventual differences between the pairs of the same items at both times of measurement. With the individual factors that have contributed to the creation of beliefs of students, we calculated the frequency for both times of measurement, and the differences in the frequency of selected factors between the two measurements that were determined with Cochran's Q test (in the case of statistical significance, the McNamar's chi-square test will be used for paired factors in $\mathrm{T}_{1}$ and in $\mathrm{T}_{2}$ ).

\section{Results and discussion}

In their answers about what contributes to the pupil's academic achievement, i.e. children, teachers, parents, and peers (Table 1), the students recognised all four proposed factors as more or less important for pupil's academic achievement. This may indicate students' beliefs about children's, teachers', parents' and peers' shared responsibilities for the pupil's academic achievement. In relation to the idea of being a good teacher, this means that the teacher cannot be fully responsible for the students' academic achievement. 
Table 1

The proportions of factors that, in the opinion of students, contribute to academic achievement of the pupil

\begin{tabular}{lccccc}
\hline & \% & $\begin{array}{c}\text { Mean } \\
\text { Rank }\end{array}$ & $\begin{array}{c}\text { Sum of } \\
\text { Rank }\end{array}$ & $\begin{array}{c}\text { Wilcoxon signed } \\
\text { rank test }\end{array}$ & Differences \\
\hline \multirow{2}{*}{ Child } & $\mathrm{T}_{1}=32.24$ & 22.00 & 506,00 & $\begin{array}{c}\mathrm{Z}=1.49 \\
\mathrm{p}=.14\end{array}$ & $\mathrm{~T}_{1}=\mathrm{T}_{2}$ \\
& $\mathrm{~T}_{2}=34.30$ & 29.29 & 820,00 & $\mathrm{Z}=-3.96$ & $\mathrm{~T}_{2}>\mathrm{T}_{1}$ \\
\hline \multirow{2}{*}{ Teacher } & $\mathrm{T}_{1}=17.69$ & 15.90 & 159.00 & $\mathrm{p}=.00$ & \\
& $\mathrm{~T}_{2}=24.04$ & 24.44 & 831.00 & $\mathrm{Z}=-1.94$ & $\mathrm{~T}_{1}>\mathrm{T}_{2}$ \\
\hline \multirow{2}{*}{ Parents } & $\mathrm{T}_{1}=29.47$ & 25.71 & 745.50 & $\mathrm{p}=.05$ & \\
\hline \multirow{2}{*}{ Peers } & $\mathrm{T}_{2}=26.18$ & 21.25 & 382.50 & $\mathrm{Z}=-3.27$ & $\mathrm{~T}_{1}>\mathrm{T}_{2}$ \\
& $\mathrm{~T}_{1}=20.58$ & 24.48 & 710.00 & $\mathrm{p}=.01$ & \\
\hline
\end{tabular}

Note. $\mathrm{T}_{1}=$ beginning of the study, $\mathrm{T}_{2}=$ end of the study.

The students attributed the largest share of the responsibility for the academic achievement of pupils at both measurements to the child himself $\left(\mathrm{T}_{1}=32 \%\right.$, $\mathrm{T}_{2}=34 \%$ ); the differences in proportion between the two measurements are not shown to be significant. Even the results of other studies, in which the factors of academic achievement were determined with various psychological tests, show that the most important factor is the specific pupil's (psychological) characteristics, among which the strongest predictors were mainly the pupil's personality traits (especially conscientiousness) and intellectual abilities (Puklek Levpušček \& Zupančič, 2009; Smrtnik Vitulić \& Zupančič, 2013). This is in line with the understanding of a good teacher as being not mainly responsible for students' academic achievement; the pupils themselves are more responsible for their academic achievement.

During both measurements, the students, among the factors of academic achievement, attributed the second highest proportion to parents (this share decreased significantly from the initial $\mathrm{T}_{1}=29 \%$ to $\mathrm{T}_{2}=26 \%$ at the end of the study). In third place, according to the attributed shares, are the teachers (the role of the teacher is significantly increased from the initial $\mathrm{T}_{1}=18 \%$ to $\mathrm{T}_{2}=24 \%$ at the end of the study). Among all four offered factors of academic achievement, the smallest share was attributed to peers (at the end of the study, their importance has significantly reduced from the initial $\mathrm{T}_{1}=21 \%$ to the final $\left.\mathrm{T}_{2}=15 \%\right)$. It is interesting that during the two measurements the students placed the role of the teacher in the academic achievement of the pupil to the third place of importance. Perhaps the students who are educated for the teaching profession do not want to take too much (shared) responsibility for the pupil's academic achievement, although 
they are certainly more responsible for the teaching and learning process than the pupil's parents, which is also recognised by Wang et al. (1993). However, it is difficult to predict precisely the size of the effects of individual factors since the effect of individual factors of academic achievement can be interactive and/or indirect (Puklek Levpušček \& Zupančič, 2009).

In this study, we also wanted to determine the beliefs of students on good teachers (Table 2). In the analysis of the results obtained, we consider the following criteria: $2.0 \leq M \leq 4$ were interpreted as average results, $M>4.0$ were interpreted as idealised beliefs of a good teacher, and $M<2.0$ as a disagreement with an individual item. At the beginning of the study, the results showed mostly idealised beliefs of students about good teachers, but at the end of the study they became more realistic: the teacher is calm and self-controlled in all situations $\left(M_{1}=4.27, M_{2}=3.85\right)$, likes all children equally $\left(M_{1}=4.63, M_{2}=3.83\right)$, has the ability to motivate all children, even those who are not interested in the subject $\left(M_{1}=4.78, M_{2}=4.17\right)$ and is able to teach the students with lower abilities $\left(M_{1}=4.12, M_{2}=3.59\right)$. These beliefs of students at the beginning of the study are unrealistic because a teacher is only 'a person' who cannot fully realise them (e.g. Gordon, 1983; Sutton, 2004).

Table 2

Students' beliefs of good teachers at the beginning and at the end of the study

\begin{tabular}{|c|c|c|c|c|c|}
\hline & $M$ & $\begin{array}{l}\text { Mean } \\
\text { Rank }\end{array}$ & $\begin{array}{l}\text { Sum of } \\
\text { Rank }\end{array}$ & $\begin{array}{l}\text { Wilcoxon signed } \\
\text { rank test }\end{array}$ & Differences \\
\hline \multirow{2}{*}{$\begin{array}{l}\text { A good teacher is calm and } \\
\text { self-controlled in all situations }\end{array}$} & $M_{1}=4.27$ & 20.80 & 582.50 & \multirow{2}{*}{$\begin{array}{c}Z=-2.82 \\
p=.01\end{array}$} & \multirow{2}{*}{$\mathrm{T}_{1}>\mathrm{T}_{2}$} \\
\hline & $M_{2}=3.85$ & 17.95 & 197.50 & & \\
\hline \multirow{2}{*}{$\begin{array}{l}\text { It is good that a teacher does } \\
\text { not show negative emotions in } \\
\text { the classroom }\end{array}$} & $M_{1}=3.76$ & 26.38 & 1240.00 & \multirow{2}{*}{$\begin{array}{c}Z=-5.78 \\
p=.00\end{array}$} & \multirow[b]{2}{*}{$\mathrm{T}_{1}>\mathrm{T}_{2}$} \\
\hline & $M_{2}=2.24$ & 21.50 & 86.00 & & \\
\hline \multirow{2}{*}{$\begin{array}{l}\text { A good teacher likes all chil- } \\
\text { dren equally }\end{array}$} & $M_{1}=4.63$ & 17.71 & 513.50 & \multirow{2}{*}{$\begin{array}{l}Z=-4.10 \\
p=.00\end{array}$} & \multirow{2}{*}{$T_{1}>T_{2}$} \\
\hline & $M_{2}=3.83$ & 11.88 & 47.50 & & \\
\hline \multirow{2}{*}{$\begin{array}{l}\text { A good teacher knows how to } \\
\text { motivate everyone, even those } \\
\text { who are not interested in the } \\
\text { subject }\end{array}$} & $M_{1}=4.78$ & 15.04 & 376.00 & \multirow{2}{*}{$\begin{array}{c}Z=-4.24 \\
p=.00\end{array}$} & \multirow{2}{*}{$\mathrm{T}_{1}>\mathrm{T}_{2}$} \\
\hline & $M_{2}=4.17$ & 10.00 & 30.00 & & \\
\hline \multirow{2}{*}{$\begin{array}{l}\text { A good teacher knows how } \\
\text { to teach the pupils with lower } \\
\text { abilities }\end{array}$} & $M_{1}=4.12$ & 18.95 & 549.50 & \multirow{2}{*}{$\begin{array}{l}Z=-3.11 \\
p=.00\end{array}$} & \multirow{2}{*}{$\mathrm{T}_{1}>\mathrm{T}_{2}$} \\
\hline & $M_{2}=3.59$ & 19.19 & 153.50 & & \\
\hline
\end{tabular}

Note. $M_{1}=$ beginning of the study, $M_{2}=$ end of the study.

The results indicate when students start their studies they mainly have ideals about being a teacher that do not allow that teachers to be subjective in 
their experience of children, that the teacher's task is to motivate all pupils, and that the teacher has complete responsibility to the extent that the pupils will learn the subject. The last finding (that the teacher is entirely responsible for how much the pupils will learn) is inconsistent with the shares of the responsibility for pupil's academic achievement when students placed teachers' responsibility only to the third place. A possible interpretation of this is that the differences arise from the use of different types of questions.

At the end of the study, the students significantly changed the majority of their idealised beliefs, except for the statement that the teacher is able to motivate all pupils, including those who are not interested in the subject $\left(\mathrm{M}_{2}=\right.$ 4.17), which remained as an idealised belief. This means that through the study, the students maintained the belief that teachers are mainly responsible for the pupils' learning motivation, which is probably due to the very present thesis in this environment that the external motivation is crucial to stimulate internal motivation. Indeed, school requires pupils to learn about many scientific, cultural and economic fields, so it is/should be the teacher's duty in particular through real pedagogical eros (Gogala, 2005), to provide enthusiasm for these fields, and the motivation to continue learning. Despite this, there remains the question of where to draw the line between idealism and actual responsibility of the teacher for the pupil's learning motivation? Since beliefs guide an individual's perceptions, understanding, and performance (Pajares, 1992; Xu, 2012), it is therefore possible that in the teacher's viewpoint, the pupil's lack of interest in the subject is interpreted in terms of their own failure.

Students were initially more inclined to agree that it is good that the teacher in the classroom does not show negative emotions, $\left(M_{1}=3.76\right)$ than at the end of the study $\left(\mathrm{M}_{2}=2.24\right)$ when they predominantly expressed disagreement with that statement. The obtained results indicate the students' belief (especially at the end of their studies) that the teacher can express unpleasant emotions in front of the pupils, such as anger, fear, shame, sadness etc., which were also present when observing interactions of Slovenian teachers with pupils in the classroom (e.g. Prosen et al., 2011). Since the teachers also represent a model for the pupils (Bandura, 1997), how they express their emotions is important. In study programmes, it would be necessary to encourage students to develop emotion regulation that specifically allows the expression of unpleasant emotions in an appropriate way. These strategies may help the teachers to improve teaching and learning in their classroom (e.g. Prosen et al., 2011). Teacher's effective emotion regulation may contribute to better teacher-pupil relationships that allow good conditions for learning (e.g. Prosen et al., 2011).

The average results regarding the statements of the pupil's developmental characteristics (Table 3 ) will be interpreted according to the same criteria as 
the arguments of a good teacher. From the results obtained, we can conclude that even at the beginning of their studies the students understand that not only heredity contribute to an individual's development $\left(M_{1}=2.31\right)$, the abovementioned understanding is similarly reflected also at the end of the study $\left(\mathrm{M}_{2}=\right.$ 2.05) (e.g. Plomin, 2004). For the (future) teachers, one of the key findings is that the environment, which is provided to a child through instruction and encouragement, has a significant impact on the expression of genes and contributes to the development of a child. According to the initial partial agreement of the students that early experiences decisively influence the child's development $\left(M_{1}=2.54\right)$, we can conclude that at the end of their studies the students are significantly more aware of the importance of subsequent experiences that have a significant impact on development $\left(\mathrm{M}_{2}=2.07\right)$. Researchers agree that there are sensitive periods in development, representing an optimal time to encourage certain abilities (e.g. language acquisition in early development), but this does not mean that individuals cannot develop certain abilities later, or compensate unfavourable (early) experiences (Bregant, 2012). According to the partial (dis) agreement of students with the assumption that a child who knows a lot of information is clever (they agree less with this statement upon the completion of studies, $M_{2}=2.53$ than at the beginning, $M_{1}=3.24$ ), one can assume that students differentiate between the two notions. Researchers also agree with the differentiation between these notions. Certainly, the knowledge of a large amount of information cannot be equated with intelligence; knowledge of the information in some intelligence tests (e.g. Wechsler, 2001, in Marjanovič Umek \& Svetina, 2004) represents only one of the subsections of intelligence.

Table 3

Students beliefs about a pupil's developmental characteristics at the beginning and at the end of their studies

\begin{tabular}{lccccc}
\hline & $M$ & $\begin{array}{c}\text { Mean } \\
\text { Rank }\end{array}$ & $\begin{array}{c}\text { Sum of } \\
\text { Rank }\end{array}$ & $\begin{array}{c}\text { Wilcoxon signed } \\
\text { rank test }\end{array}$ & Differences \\
\hline $\begin{array}{l}\text { Heredity determines the devel- } \\
\text { opment of individuals from birth } \\
\text { to death }\end{array}$ & $\mathrm{M}_{1}=2.31$ & 18.23 & 401.00 & $\mathrm{Z}=-1.45$ & $\mathrm{~T}_{2}=\mathrm{T}_{1}$ \\
\hline $\begin{array}{l}\text { Experience from early childhood } \\
\text { has a decisive influence on child } \\
\text { development }\end{array}$ & $\mathrm{M}_{1}=2.05$ & 17.62 & 229.00 & $\mathrm{p}=.15$ & $\mathrm{Z}=-3.27$ \\
\hline $\begin{array}{l}\text { There are no significant differ- } \\
\text { ences in cognitive abilities of } \\
\text { pupils of the same class }\end{array}$ & $\mathrm{M}_{2}=2.07$ & 16.00 & 192.00 & $\mathrm{p}=.00$ & $\mathrm{~T}_{1}>\mathrm{T}_{2}$ \\
\hline
\end{tabular}




\begin{tabular}{lccccc}
\hline & $M$ & $\begin{array}{c}\text { Mean } \\
\text { Rank }\end{array}$ & $\begin{array}{c}\text { Sum of } \\
\text { Rank }\end{array}$ & $\begin{array}{c}\text { Wilcoxon signed } \\
\text { rank test }\end{array}$ & Differences \\
\hline $\begin{array}{l}\text { A child who knows a lot of infor- } \\
\text { mation is clever }\end{array}$ & $M_{1}=3.24$ & 20.02 & 660.50 & $\mathrm{Z}=-4.36$ & $\mathrm{~T}_{1}>\mathrm{T}_{2}$ \\
\hline $\mathrm{M}_{2}=2.53$ & 16.10 & 80.50 & $\mathrm{p}=.00$ & \\
\hline $\begin{array}{l}\text { School is not a place to learn } \\
\text { how to express feelings }\end{array}$ & $\mathrm{M}_{1}=1.75$ & 15.89 & 429.00 & $\mathrm{Z}=-4.28$ & $\mathrm{~T}_{1}>\mathrm{T}_{2}$ \\
\hline $\mathrm{M}_{2}=1.22$ & 12.00 & 36.00 & $\mathrm{p}=.00$ & \\
\hline
\end{tabular}

Note. $M_{1}=$ beginning of the study, $M_{2}=$ end of the study.

Based on the results obtained when students at the beginning of the study mostly did not agree with the statement that there are no significant differences in their mental abilities among the pupils of the same class $\left(M_{1}=2.25\right)$, we assume that students at the entry into the study recognise individual differences in the cognitive abilities of the children of similar age, while at the end of the study they largely disagree with the abovementioned findings $\left(M_{2}=1.86\right)$. The beliefs of students are consistent with the developmental findings that children of the same age have various mental abilities (Piaget \& Inhelder, 1978). Understanding the individual differences between the mental abilities of children is also a condition that the teacher is willing to adapt the way of teaching to students' abilities and thus enable the optimal development of pupils of different abilities. At both times of measurement, students largely did not agree with the statement that school is not a place to learn how to express emotions $\left(M_{1}=1.75\right.$, $\left.M_{2}=1.22\right)$. We can conclude that students, upon entry into the study and at the end of the study, believe that pupils and teachers can express emotions in the school context, which enables open 'space' for learning to express emotions in the classroom. Based on our results, we can conclude that the students reshape their beliefs about the teacher and students during the course of their studies towards more realistic and research-supported findings (Korthagen, 2004).

In the last part of the questionnaire, students are offered a choice between the factors that have contributed to their (re)shaping of beliefs about a good teacher and developmental characteristics of the children (Table 4). 
Table 4

(Un)important factors of shaping students' beliefs at the beginning and at the end of the study

\begin{tabular}{lcccc}
\hline & $\begin{array}{c}\mathrm{T}_{1}(\mathrm{f}) \\
\text { Unimportant }\end{array}$ & $\begin{array}{c}\mathrm{T}_{2} \text { (f) } \\
\text { Unimportant }\end{array}$ & $\begin{array}{c}\mathrm{T}_{1} \text { (f) } \\
\text { Important }\end{array}$ & $\begin{array}{c}\mathrm{T}_{2} \text { (f) } \\
\text { Important }\end{array}$ \\
\hline Lectures at the faculty & 56 & 30 & 1 & 27 \\
Tutorials and seminars at the faculty & 54 & 30 & 3 & 27 \\
Direct experience in the classroom & 17 & 4 & 40 & 53 \\
Direct experience in the domestic environment & 30 & 29 & 27 & 28 \\
Experiences in the family & 28 & 37 & 29 & 20 \\
Others & 53 & 54 & 4 & 3 \\
\hline Total & 238 & 184 & 104 & 158 \\
\hline
\end{tabular}

At the beginning of the study, the students most commonly selected the following factors as important: direct experience in the classroom (40 answers), experience in the family (29 answers) and home environment (27 answers). Upon completion of the studies, the students expressed that the most influential factors were: direct experience in the classroom ( 53 answers), direct experience in the domestic environment ( 28 answers), lectures at the faculty (27 answers), tutorial and seminars (27 answers), as well as experiences in the family (20 answers).

A comparison of the frequency of answers regarding the factors of establishing their beliefs obtained at the beginning and end of the study showed significant differences between the two measurement times (Cochran' Q test $(11)=218.92, p=.00)$. Due to the significant differences between factors during both measurements, we calculated the McNemar's chi-square test that was used for paired factors in $\mathrm{T}_{1}$ and in $\mathrm{T}_{2}$ (Table 5 ).

Table 5

McNemar's chi square tests for all 15 paired combinations between 6 factors in $T_{1}$ and in $T_{2}$.

\begin{tabular}{lll}
\hline & \multicolumn{1}{c}{$\mathrm{T}_{1}$} & \multicolumn{1}{c}{$\mathrm{T}_{2}$} \\
\hline 1 & Lecture $=$ Tutorial/Seminars & Lecture $=$ Tutorial $/$ Seminars \\
2 & Lecture $<$ Classroom* & Lecture $<$ Classroom* \\
3 & Lecture $<$ Domestic* & Lecture $=$ Domestic \\
4 & Lecture $<$ Family* & Lecture $=$ Family \\
5 & Lecture $=$ Others & Lecture $>$ Others $*$ \\
6 & Tutorial/Seminars $<$ Classroom* & Tutorial $/$ Seminars $<$ Classroom* \\
\hline
\end{tabular}




\begin{tabular}{lll}
\hline & \multicolumn{1}{c}{$\mathrm{T}_{1}$} & \multicolumn{1}{c}{$\mathrm{T}_{2}$} \\
\hline 7 & Tutorial/Seminars < Domestic* & Tutorial/Seminars = Domestic \\
8 & Tutorial/Seminars < Family* & Tutorial/Seminars = Family \\
9 & Tutorial/Seminars = Others & Tutorial/Seminars $>$ Others* \\
10 & Classroom > Domestic** & Classroom > Domestic* \\
11 & Classroom = Family & Classroom $>$ Family* \\
12 & Classroom $>$ Others* & Classroom $>$ Others* \\
13 & Domestic $=$ Family & Domestic $=$ Family \\
14 & Domestic $>$ Others* & Domestic $>$ Others* \\
15 & Family $>$ Others* & Family $>$ Others* \\
\hline
\end{tabular}

Note. ${ }^{*}$ significant differences between factors $(p=.000)$; ${ }^{* *}$ significant differences between factors ( $p=.041)$.

In $\mathrm{T} 1,10$ statistically significant differences between all 15 pairs of factors could be seen; in $\mathrm{T} 2$, there were nine differences. The results show that at the beginning of the study students' experiences in class were the most significant for the creation of their beliefs while the family and domestic environment were less significant. Students at the end of the education emphasise the importance of their direct experience in the classroom, while lectures and tutorial and seminars can be seen as equally important as the domestic environment and family. At the beginning and at the end of the study, students chose direct experiences in the classroom as the most important factor, which is in accordance with the findings of various authors (e.g. Korthagen, 2004; Valenčič Zuljan, 2012).

The assessed lower influence of lectures, tutorials, and seminars on the transformation of beliefs may be a consequence of a deeper, but widespread belief that theory and practice are not strongly related, or that there is a large gap between them, and in this sense (theoretical) lectures cannot have a significant impact on the change in beliefs. However, in the future, we should encourage all those who design study programmes for teachers to consider how, with the change of individual contents and methods of work, they may enable the reshaping of those beliefs of students about a good teacher and the characteristics of pupils that appear to be less real or effective in the classroom.

\section{Conclusions}

In the longitudinal study, we determined the beliefs of the primary education students regarding the factors of academic achievement, being a good teacher, and developmental characteristics of children, and explored which experiences mostly shaped these beliefs. During both measurements (at the beginning and at the end of the study), students attributed the largest share 
of the responsibility for the academic achievement of pupils to themselves (no significant differences found), then to parents (the proportion decreased significantly from the initial to the final assessment). As third most significant, students attributed teachers as being responsible for pupils' academic achievement (the role of the teacher is significantly increased from the initial to the end of the study). Among all four offered factors of academic achievement, the smallest share was attributed to peers (at the end of the study, their importance was significantly reduced from the initial to the final).

We found that students start their studies with mostly idealised beliefs about good teacher: the teacher is calm and self-controlled in all situations, the teacher likes all children equally, the teacher can motivate all children, including those who are not interested in the subject, and the teacher is able to teach the pupils with lower abilities. During their studies, students managed to reshape most of these beliefs into more realistic ones, with the exception of the belief that the teacher can motivate all children, including those who are not interested in the subject.

Regarding the developmental characteristics of children, during both measurements, students had similar beliefs that heredity and environment contribute to an individual's development, but at the second measurement the students were significantly more convinced that experience from an early age decisively influences the less development, that there are no major differences in cognitive abilities of pupils of the same class, that a child who knows a lot of information is clever, and that school is not a place for the expression of emotions.

During both measurements, the students expressed different factors of influence that contributed to their beliefs. At the beginning of the study, experiences in classroom were the most significant for the creation of students' beliefs while the student's family and domestic environment were less important. Students at the end of their education stressed the importance of their direct experience in the classroom, while lectures, tutorials, and seminars were seen as equally important as the domestic environment and family.

In the study, the sample of students was somewhat small. Future research could involve a larger group of students/teachers from different universities/schools. Furthermore, other ways of gathering data on beliefs might be considered, such as interviews with students and teachers.

There are various ways to consider the applicative value of the present study. Students may change many of their ideas about being a teacher and the pupils mostly with particular experience in the classroom which they were given as pupils, as well as through practical teaching education at the university. It 
would be advisable that with direct teaching during the education of students (lectures, tutorials, and seminars), we promote on the basis of a different theory a reflection of students' beliefs that are of key importance for their future work. Undoubtedly, much attention in the academic process should be given to the raising of awareness of students, that their work in the future will require constant questioning of how the beliefs about good teachers in everyday teaching practices should be achieved, and a continuous reflection on how their beliefs are consistent with the values of excellence, ethics, and engagement ('the 3 E's') (Gardner, 2010).

\section{References}

Bandura, A. (1997). Self-efficacy: The exercise of control. New York, NY: Freeman and Company.

Bečaj, J. (1990). Problem velikih pričakovanj in učiteljeve odgovornosti: Učiteljeva pričakovanja in odgovornost $\mathrm{v}$ Gordonovem komunikacijskem treningu [The problem of high expectations and responsibilities of the teacher: The teacher expectations and responsibility in Gordon's communication training]. Ljubljana: Svetovalni center za otroke, mladostnike in starše.

Bregant, T. (2012). Razvoj, rast in zorenje možganov [Brain development, growth, and maturation]. Psihološka obzorja, 21(2), 51-6o.

Doolittle, S. A., Dodds, P., \& Placek, J. H. (1993). Persistence of beliefs about teaching during formal training of preservice teachers. Journal of Teaching in Physical Education, 12, 355-365.

Fajet, W., Bello, M., Leftwich, S. A., Mesler J. M., \& Shaver, A. N. (2004). Pre-service teachers' perceptions in beginning education classes. Teaching and Teacher Education, 21(6), 717-727.

Gardner, H. (2010). Introduction. In H. Gardner (Ed.), GoodWork: Theory and practice (pp. 1-21). Retrieved from http://www.thegoodproject.org/pdf/GoodWork-Theory_and_Practice-with_covers.pdf Gogala, S. (2005). Izbrani pedagoški spisi [Selected educational papers]. Ljubljana: Društvo 2000.

Gordon, T. (1983). Trening večje učinkovitosti za učitelje [Efficiency training for teachers]. Ljubljana: Svetovalni center.

Guidebook: GoodWork toolkit: Excellence, ethics, engagement (2010). The presidents and fellows of Harvard College on behalf of project Zero. Retrieved from http://www.thegoodproject.org/pdf/ GoodWork-Toolkit-guide.pdf

Hermans, R., van Braak, J., \& Van Keer, H. (2008). Development of the beliefs about primary education scale: Distinguishing a developmental and transmissive dimension. Teaching and Teacher Education, $24(1), 127-139$.

Hosotani, R., \& Imai-Matsumura, K. (2011). Emotional experience, expression, and regulation of highquality Japanese elementary school teachers. Teaching and Teacher Education, 27(6), 1039-1048.

Howard Jones, P. (2010). Introducing neuroeducational research. London, UK: Routledge.

Kail, R. V., \& Cavanaugh, J. C. (2016). Human development: A life-span view (7th ed.) Belmont, TN: Wadsworth. 
Korthagen, F. A. J. (2004). In search of the essence of a good teacher: Towards a more holistic approach in teacher education. Teaching and Teacher Education, 20(1), 77-97.

Krek, J., \& Metljak, M. (Ed.) (2011). Bela knjiga o vzgoji in izobraževanju v Republiki Sloveniji [White book on education in the Republic of Slovenia]. Ljubljana: Zavod RS za šolstvo.

Lofstrom, E., \& Poom-Valickis, K. (2013). Beliefs about teaching: Persistent or malleable? A longitudinal study of prospective student teachers' beliefs. Teaching and Teacher Education, 35, 104-113.

Marjanovič Umek, L., \& Svetina, M. (2004). Spoznavni in govorni razvoj v srednjem in poznem otroštvu [Cognitive and language development in middle and late childhood]. In L. Marjanovič Umek \& M. Zupančič (Eds.), Razvojna psihologija (pp. 408-427). Ljubljana: Znanstvenoraziskovalni inštitut Filozofske fakultete.

Minor, L. C., Onwuegbuzie, A. J., Witcher, A. E., \& James, T. L. (2002). Preservice teachers' educational beliefs and their perceptions of characteristics of effective teachers. The Journal of Educational Research, 96(2), 116-127.

Mishima, T., Horimoto, A., \& Mori, T. (2010). Changes in the images of teaching, teachers, and children expressed by student teachers before and after student teaching. Psychological Reports, 106(3), 769-784. Pajares, M. F. (1992). Teachers' beliefs and educational research: Cleaning up a messy construct. Review of Educational Research, 62(3), 307-332.

Piaget, J., \& Inhelder, B. (1978). Intelektualni razvoj deteta [Intellectual development of a child]. Beograd: Zavod za udžbenike in nastavna sredstva.

Plomin, R. (2004). Nature and nurture. An introduction to human behavioral genetics. Belmont, TN: Wadsworth.

Prosen, S., Smrtnik Vitulić, H., \& Poljšak-Škraban, O. (2011). Teachers' emotional expression in interaction with students of different ages. CEPS Journal, 1(3), 141-157.

Protner, E. (200o). Pedagogika in izobraževanje učiteljev (1919-1941) [Pedagogy and teacher education (1919-1941)]. Nova gorica: Educa.

Puklek Levpušček, M., \& Zupančič, M. (2009). Osebnostni, motivacijski in socialni dejavniki učne uspešnosti [Personal, motivational and social factors of school achievement]. Ljubljana: Znanstvenoraziskovalni inštitut Filozofske fakultete.

Sanders, S. E. (2002). What do schools think makes a good mathematics teacher? Educational Studies, $28(2), 181-191$.

Šarić, M. (2015). Čustva učiteljev: pregled raziskav s psihološke perspektive [Teachers' emotions: a research review from a psychological perspective]. Sodobna pedagogika, 66(4), 10-26.

Šimonka, Z., \& Košir, K. (2014). Odnos med prepričanji in spoprijemanjem z negativnimi čustvi v razredu pri učiteljih osnovne šole [Relationship between primary school teachers 'beliefs and coping with negative emotions in the classroom]. Revija za elementarno izobraževanje, 7(3/4), 33-48.

Smrtnik Vitulić, H., \& Zupančič, M. (2013). Robust and specific personality traits as predictors of adolescents' final grades and GPA at the end of compulsory schooling. European Journal of Psychology of Education, 28(4), 1181-1199.

Smrtnik Vitulić, H. (2009). Spoznavanje otrok v razredu [Understanding children in class]. Ljubljana: 
Pedagoška fakulteta.

Sutton, R. E. (2004). Emotional regulation goals and strategies of teachers. Social Psychology of Education, 7(4), 379-398.

Thomas, L., \& Beauchamp, C. (2011). Understanding new teachers' professional identities through metaphor. Teaching and Teacher Education, 27(4), 762-769.

Valenčič Zuljan, M. (2012). Profesionalne poti pedagoških delavcev [Professional pathways of pedagogical workers]. Vršac: Visoka škola strukovnih studija za obrazovanje vaspitača »Mihailo Palov«.

Wang, M. C., Haertel, H. J., \& Walberg, H. J. (1993). Towards a knowledge base for school learning. Review of Educational Research, 63(3), 249-294.

$\mathrm{Xu}$, L. (2012). The role of teachers' beliefs in the language teaching-learning process, Theory and Practice in Language Studies, 2(7), 1397-1402.

\section{Biographical note}

Helena Smrtnik Vitulić, PhD in psychology, is Associate Professor of Developmental Psychology at the Faculty of Education, University of Ljubljana, Slovenia. Her major research interests include emotion development and emotion regulation, personality and academic achievement, social development, deaf and hard of hearing students and Creative Movement as teaching method.

Irena Lesar, PhD, Associate Professor, is teaching and researching at the Faculty of Education and Academy of Music, University of Ljubljana. She completed her Honours Degree in Pedagogy and Sociology of Culture (1998), Master of Science (2002) and received her Doctor of Science in Pedagogy (2007) at University of Ljubljana, Faculty of Arts. In the last decade her research is focused on the conceptualization of justice and inclusion, the status of various marginalized groups, in particular Roma, (new) immigrants and SEN students in Slovenian schools through their social participation and academic achievement. More recently, she focuses on the question of the beliefs of (future) teachers and the possibility of their change through the education process. 